\title{
On Innovation of Science Teacher Training and its Evaluation
}

\author{
Petr Emanovský, Bronislava Štěpánková \\ Palacký University Olomouc
}

\begin{abstract}
Improving the quality of science education is unthinkable without a quality science teacher training at universities and other educational institutions. The paper deals with some innovation possibilities of the study programme for future science teachers realized within ESF project "Professional science teacher training for careers in a competitive environment" at Faculty of Science of Palacký University in Olomouc, Czech Republic. One of the main aims of the project is the creation of innovated curricula and special textbooks for these programmes. A complete evaluation was carried out to strengthen the feedback from pilot teaching of new and innovated subjects as well as the new teaching practice. The aim of the evaluation was to determine the difference between expectations and real benefits of the subjects and the practice. The evaluation results are very useful as a feedback for a subsequent modification of the study programs.
\end{abstract}

\section{Introduction}

According to Westat [7], the current view of evaluation stresses the inherent interrelationships between evaluation and programme implementation. Evaluation is not separate from, or added to, a project, but is rather part of it from the beginning. Planning, evaluation, and implementation are all parts of a whole, and they work best when they work together. Other interesting features of the evaluation process are presented by Lamanauskas [4], Bentley and Watts [1], Black and Wiliam [2] or Guba and Lincoln [3].

For an evaluation of process of science teaching and learning there are different strategy and ways. The main questions are: What is to be evaluated? When and why to evaluate? How to evaluate? It is clear that for science teaching success one of the most important resources is feedback from students (Lamanauskas, V., Vilkoniené, M., [5]).

\section{Characterization of the project}

The project objective is to improve the training of teachers of science subjects in line with the growing needs of the current competitive labour market. One of the main aims of the project leading to this improvement is the creation of innovated curricula for teacher training in mathematics, physics, chemistry, biology and geography at the Faculty of
Science at Palacký University in Olomouc, including a common base and teaching practice. Within this key activity new syllabi of some selected subjects were created and study textbooks were specifically treated for teaching these subjects. Pilot teaching of the innovated subjects is aimed at testing the innovated items on the target group of science teacher training students. A feedback based on the evaluation of the pilot teaching is used to modify the content of the final innovated subjects before their inclusion in regular study programme. Another objective of the project is the creation and development of university schools system in the region of Palacký University, in particular for the purpose of the implementation of the newly conceived student teaching practice. University schools will also be used to realize education research of students and university teachers and systematic work with potential applicants to study at the Faculty of Science at Palacký University.

The project target group consists primarily of students studying teacher training programme of natural sciences at the Faculty of Science, as well as secondary school students (potential applicants for the study at the Faculty of Science) and university teachers involved in training of the future teachers. The support for secondary school students is implemented within the project mainly by popularizing events, competitions, educational seminars, etc. Educational events thematically focused on the needs of teaching practice are organized for the target group of university teachers and students.

\section{Evaluation of innovated teaching and teaching practice}

The starting point for the evaluation was whether the teaching of new subjects which were integrated into study programmes would be helpful for students. Another question was whether the newly conceived concept of teaching practice would be more beneficial for students and also for their experienced supervising teachers than the old concept. The form of a questionnaire was chosen as a method of evaluation. Four research tools questionnaires - were developed. Two were designed for evaluation of teaching and two for the evaluation of the teaching practice. The evaluation of the whole project is divided into the evaluation of the teaching of new subjects included in the study programme and the evaluation of the teaching practice in a new 
concept. The first part of evaluation runs twice each semester, always at the beginning of the semester and at the end of the semester when those subjects are taught. The evaluation of the teaching practice is different. The teaching practice is also assessed twice; the first time from the perspective of a practicing student who gains teaching experience at school and the second time from the perspective of an experienced teacher with whom the student held the practice. These two forms of evaluation are always carried out at the end of the practice.

\subsection{Partial evaluation of innovated teaching}

Using the questionnaires during the evaluation of teaching of new subjects there were compared the expectations of students at the beginning of the course with the fulfilment of the expectations at the end, i.e. with their evaluation of teaching the subject throughout the semester. For this reason, the evaluation took place immediately at the beginning of teaching, i.e. in the first lesson of the subject. As a research tool, the questionnaire was used which investigated whether students expectations of this course were to acquire new knowledge, skills in practical or theoretical platform, whether they expected well-prepared teachers, and whether a motivation for choosing the subject was their interest. The evaluation questionnaire that students filled out at the end of teaching the subject, again carried the questions relating to the acquisition of new knowledge, and practical and theoretical skills. Other questions related to the quality of the professional preparedness of the teachers, the subject content - whether the students were interested in the subject, whether the form of implementation suited them, whether the issue was new and rewarding for them, whether they had enough quality literature and whether they would chose the subject again. Finally, the students rated the subject with a mark from 1 to 5 , where 1 meant the best rating and 5 was the worst one. All questions except the last one were multiplechoice questions, the possible answers being: yes, partly, no, no answer. The questions were deliberately formulated with closed response options because of easier statistical processing. The questionnaires were designed as follows:

\section{PRE-COURSE EVALUATION QUESTIONNAIRE}

Circle your answer (one option only):

1. Do you expect that you acquire new knowledge by completion of this course?

\begin{tabular}{|l|l|l|l|}
\hline yes & partially & no & no answer \\
\hline
\end{tabular}

2. Do you expect that you acquire new skills by completion of this course?

\begin{tabular}{|l|l|l|l|}
\hline yes & partially & no & no answer \\
\hline
\end{tabular}

3. Do you think that you will get more:

\begin{tabular}{|l|l|l|l|}
\hline $\begin{array}{l}\text { theoretical } \\
\text { knowledge }\end{array}$ & practical skills & $\begin{array}{l}\text { just the } \\
\text { same }\end{array}$ & $\begin{array}{l}\text { no } \\
\text { answer }\end{array}$ \\
\hline
\end{tabular}

4. Do you expect well-prepared teachers?

\begin{tabular}{|l|l|l|l|}
\hline yes & partially & no & no answer \\
\hline
\end{tabular}

5. What was the reason for your choice of the subject?

\begin{tabular}{|l|l|l|l|l|}
\hline credits & topic & teacher & $\begin{array}{l}\text { other } \\
\text { reason }\end{array}$ & $\begin{array}{l}\text { no } \\
\text { answer }\end{array}$ \\
\hline
\end{tabular}

\section{POST-COURSE EVALUATION QUESTIONNAIRE}

Circle your answer (one option only):

1. Do you think that you have acquired new knowledge by completion of this course?

\begin{tabular}{|l|l|l|l|}
\hline yes & partially & no & no answer \\
\hline
\end{tabular}

2. Do you think that you have acquired new skills by completion of this course?

\begin{tabular}{|l|l|l|l|}
\hline yes & partially & no & no answer \\
\hline
\end{tabular}

3. Do you think that you have got more:

\begin{tabular}{|l|l|l|l|}
\hline $\begin{array}{l}\text { theoretical } \\
\text { knowledge }\end{array}$ & practical skills & $\begin{array}{l}\text { just the } \\
\text { same }\end{array}$ & $\begin{array}{l}\text { no } \\
\text { answer }\end{array}$ \\
\hline
\end{tabular}

4. Were the teachers well-prepared?

\begin{tabular}{|l|l|l|l|}
\hline yes & partially & no & no answer \\
\hline
\end{tabular}

5. Course content impressed you:

\begin{tabular}{|c|c|c|c|}
\hline $\begin{array}{c}\text { very } \\
\text { impressed }\end{array}$ & $\begin{array}{c}\text { moderately } \\
\text { impressed }\end{array}$ & $\begin{array}{c}\text { did not } \\
\text { impress }\end{array}$ & no answer \\
\hline
\end{tabular}

6. How do you meet the way of realization?

\begin{tabular}{|l|l|l|l|}
\hline yes & $\begin{array}{l}\text { I recommended } \\
\text { to improve it }\end{array}$ & no & no answer \\
\hline
\end{tabular}

7. Given issue was for you:

\begin{tabular}{|l|l|l|l|}
\hline $\begin{array}{l}\text { completely } \\
\text { new }\end{array}$ & $\begin{array}{l}\text { partially } \\
\text { new }\end{array}$ & $\begin{array}{l}\text { known } \\
\text { (nothing } \\
\text { new) }\end{array}$ & $\begin{array}{l}\text { known (but } \\
\text { rewarding) }\end{array}$ \\
\hline
\end{tabular}


8. Quantity and quality of educational literature:

\begin{tabular}{|l|l|l|l|}
\hline high & medium & low & no answer \\
\hline
\end{tabular}

9. Would you choose this subject again?

\begin{tabular}{|l|l|l|l|}
\hline definitely & maybe & no & no answer \\
\hline
\end{tabular}

10. Mark of overall evaluation of the course (as at school)

\begin{tabular}{|l|l|l|l|l|l|}
\hline 1 & 2 & 3 & 4 & 5 & no answer \\
\hline
\end{tabular}

\subsection{Partial evaluation of teaching practice}

There were two questionnaires to assess the teaching practice. The first one investigated the perspective of a student who had just finished his/her teaching practice at school. Here the student was asked how he or she was prepared from university in terms of knowledge and skills in the subjects of his or her qualification. Further interest was to find out whether a student was informed about educational programmes used at school. Whether he or she was able to formulate the goals of teaching, to structure a lesson, whether he or she managed to motivate pupils properly, to have contact with them, to answer their questions, to evaluate their performance, to manage educational problems. Whether he or she managed to make appropriate use of information technology, whether he or she could prepare a written examination and conduct an oral examination, whether his or her speech was comprehensible for the students. In one of the items the student was asked whether the practice was used to collect data for educational research. The last item of the questionnaire provided the students with space to comment all activities which exceeded their duties. In the second questionnaire, filled out by an experienced teacher with whom the student held the practice, were items of similar content. The teacher used them to evaluate the student practitioner. All items except the last one offered options from 1 to 4 , where 1 meant excellent and 4 unsatisfactory evaluation ratings. The research group for evaluation of the teaching was formed by all students who chose the subjects newly integrated into the study programme in the semester. Almost all the questionnaires in all new subjects were returned. It was because the teacher distributed the evaluation questionnaires at the beginning and at the end of the teaching practice personally and the students returned them to the teacher personally as well. The research group for evaluation of teaching practice in the new concept was formed by all students who realized their teaching practice in a given semester. Before starting the practice they received the evaluation questionnaires in both versions (for themselves and their teachers) from their methodologist of qualification subjects which returned to their methodologist after the practice. This ensured an almost total return. The questionnaires were designed as follows:

\begin{tabular}{|c|c|c|c|c|}
\hline QUESTIONNAIRE FOR TEACHER & 1 & 2 & 3 & 4 \\
\hline $\begin{array}{l}\text { 1. Heishe has suftcient knowledge and skils in the sucject of } \\
\text { thisher quaification and haishe is qualfied to taach at } \\
\text { secendary sthool: }\end{array}$ & & & & \\
\hline $\begin{array}{l}\text { 2. Helshe was informed about the edveatiansi programs that } \\
\text { are used at school: }\end{array}$ & & & & \\
\hline 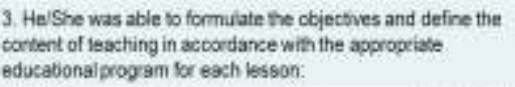 & & & & \\
\hline $\begin{array}{l}\text { 4. He/Sho was able to structure the lessons appropnately with } \\
\text { tegard to ouriculum, timetable and the pace of study. }\end{array}$ & & & & \\
\hline $\begin{array}{l}\text { 5. Heishe managed to preperly motivale students and to } \\
\text { reach their active partic pabian i learning }\end{array}$ & & & & \\
\hline $\begin{array}{l}\text { 8. HeIShe managed to make cortact with students, } \\
\text { communcate with them, Use fhe standard language and the } \\
\text { correct terminciogy. Pupis understoco himher. }\end{array}$ & & & & \\
\hline $\begin{array}{l}\text { 7. He/She managed to answer students questions and solve } \\
\text { professianal problems: }\end{array}$ & & & & \\
\hline $\begin{array}{l}\text { 8. He'She managed to use information leshnology sultable } \\
\text { demonstratonsand teachingauds: }\end{array}$ & & & & \\
\hline $\begin{array}{l}\text { 9. He/She managed to propare a written tests and to lead an } \\
\text { aral examination }\end{array}$ & & & & \\
\hline $\begin{array}{l}\text { 10. Haishe managed to evaluate the perfomance of sudents } \\
\text { using approprate classification without their comments. }\end{array}$ & & & & \\
\hline 11. HeiShe mansged to deal w th educationai problerts: & & & & \\
\hline 12. Clarty of hisher wrang was for pupis: & & & & \\
\hline
\end{tabular}

Figure 1. Teacher questionnaire for teaching practice

\begin{tabular}{|c|c|c|c|c|}
\hline QUESTIONNAIRE FOR STUDENT & 1 & 2 & 3 & 4 \\
\hline $\begin{array}{l}\text { 1. The school has presared me in lerms of knowledge and } \\
\text { skils in the sitjects of my qualification: }\end{array}$ & & & & \\
\hline $\begin{array}{l}\text { 2. was informed aboit the educsionsi programs thist are } \\
\text { used at schoot. }\end{array}$ & & & & \\
\hline 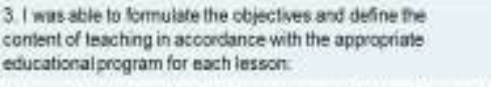 & & & & \\
\hline $\begin{array}{l}\text { 4. I was able to structure the essons appropriately with regard } \\
\text { to currounm, imetasle and the pace of study. }\end{array}$ & & & & \\
\hline $\begin{array}{l}\text { 5. I managed so peoperty mobivite studeres and to isach ther } \\
\text { sctive partic paton n leaming. }\end{array}$ & & & & \\
\hline 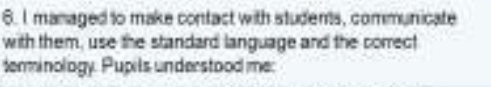 & & & & \\
\hline $\begin{array}{l}\text { 7.) maraged so answer students quesfons and solve } \\
\text { protessional problems: }\end{array}$ & & & & \\
\hline $\begin{array}{l}\text { 8. } 1 \text { masaged bo use nformasontecheicgy, suitable } \\
\text { demanstrations and teaching aids: }\end{array}$ & & & & \\
\hline $\begin{array}{l}\text { 9. I managed to prepare a witten lests and to lead an oral } \\
\text { examination. }\end{array}$ & & & & \\
\hline $\begin{array}{l}\text { 10. I manaped to evaluate fre performance of students usiog } \\
\text { asproprate classifcation wifhout their comments }\end{array}$ & & & & \\
\hline 11 I managed is desi with educationai problems: & & & & \\
\hline 12. Clanty of mywerbng was, in my openion for pupis & & & & \\
\hline
\end{tabular}

Figure 2. Student questionnaire for teaching practice 


\subsection{Data processing}

The data obtained from the questionnaires were processed into tables and graphs with absolute and relative frequencies. A comparison of responses was made at the beginning and the end of lessons, if the subjects were in a sufficient number of respondents. Thus the difference between expectations and evaluations of the subject was assessed. Similarly, the items of student and teacher evaluation of teaching practice were compared. To observe anonymity it was necessary to use the two-sample (unpaired) method, and a nonparametric method according to the type of answers (see e.g. Lodico, Spaulding and Voeghtle [6]).

Using the Mann-Whitney test for the significance level of 0.05 , statistically significant differences were investigated. The comparison could not be made in the cases where a sufficient number of respondents were not available. The evaluation was done using the system SPSS, version 12.0. Two evaluations of teaching and teaching practice were performed in the current phase of the project. In the first evaluation, teaching of the following new subjects was evaluated: Introduction to Study of Mathematics for Everyone, Current Issues of Teaching Mathematics, Fundamentals of Educational Research, Local Region in Teaching Geography, Current Issues of Teaching Geography and Current Issues of Teaching Physics.

When comparing the initial state and the final state of the subjects, no statistically significant difference was found. It can be established that new subjects met the needs of students. The practices of subjects Biology, Mathematics, Chemistry, Physics and Geography were evaluated within the first evaluation of the teaching practice. Connected answers of student and teacher responses were compared if a sufficient number of respondents were available. The chi-square test or the Fisher's test was used for the evaluation. If the requirements for these tests there were not fulfilled, the two-sample U-test was used. Everything was done using the system SPSS, version 12.0.

\subsection{Partial evaluation results}

A statistically significant difference was detected only for question number 1 in teaching Biology, where the students stated how they were prepared at university in terms of knowledge and skills for teaching the subject. The students were very critical and in 55\% claimed that they did not have sufficient knowledge and skills in the subject of their qualification compared to $96 \%$ of teachers who were convinced that students had sufficient knowledge and skills to teach at secondary school. Within the teaching practice of chemistry, a statistically significant difference was determined between the student and teacher response to the question regarding making contacts with pupils, communication with them and the use of the correct terminology. The students were convinced $100 \%$ that they spoke standard language, used the correct terminology and spoke clearly. However, the teachers argued that this was less than $60 \%$. Within the teaching practice of geography, statistically significant differences were found in seven questions. The views of the students and the teachers diverged in their responses about whether the students had enough knowledge and skills for teaching their specialisation, about knowledge of educational programmes, about the skills to formulate an objective of teaching, to structure curriculum properly, about the ability to motivate pupils, the use of suitable demonstrations, teaching aids, information technology and about the ability to mark the students according to their performance.

Teaching of the following subjects was assessed within the second evaluation: Introduction to Study of Mathematics for Everyone (USM), Current Issues of Teaching Biology (SPVB), Revision of Secondary School Geography (RSZ), Revision of Secondary School Physics (RSSF), Revision of Secondary School Chemistry (RSCH) and Fundamentals of Educational Research (ZPV). When comparing the initial state and the final state of the subjects, no statistically significant difference was found. The second teaching practice regarded the following subjects: Biology, Mathematics, Chemistry, Physics and Geography. Again, connected answers of student and teacher responses were compared if a sufficient number of respondents were available. No statistically significant difference was found in any item of any subject.

\section{Overall evaluation}

The overall evaluation was realized after four semesters of innovated teaching and practice in a similar manner. The Table 1 shows the complete list of new courses taught during years 2011 and 2012. Besides of above mentioned courses, the following new courses were implemented into the study program during these two years: Current Issues of Teaching Physics (APVF), Current Issues of Teaching Chemistry (APVCH), Current Issues of Teaching Geography (APVZ), Dynamic Models of Stereometry (DMVS), Local Region in Teaching of Geography (MR) and Cross-cutting Topics in Teaching of Geography (PTZ). 
Table 1. Innovated teaching - number of students

\begin{tabular}{|c|c|c|c|c|c|}
\hline \multirow{2}{*}{ Course } & \multicolumn{4}{|c|}{ Semester } & \multirow{2}{*}{ Total } \\
\cline { 2 - 5 } & 1. & 2. & 1. & 2. & \\
\hline APVF & 2011 & 2011 & 2012 & 2012 & \\
APVCH & 0 & 0 & 2 & 0 & 4 \\
APVM & 6 & 0 & 6 & 0 & 6 \\
APVZ & 6 & 0 & 6 & 0 & 14 \\
DMVS & 0 & 0 & 9 & 0 & 12 \\
MR & 13 & 0 & 13 & 0 & 26 \\
PTZ & 0 & 0 & 0 & 25 & 25 \\
RSCH & 0 & 9 & 0 & 4 & 13 \\
RSSF & 0 & 5 & 0 & 2 & 7 \\
RSZ & 0 & 4 & 0 & 0 & 4 \\
SPVB & 0 & 15 & 0 & 32 & 47 \\
USM & 17 & 21 & 0 & 25 & 63 \\
ZPV & 1 & 0 & 0 & 3 & 4 \\
\hline Total & 45 & 54 & 44 & 91 & 234 \\
\hline
\end{tabular}

The course Study of Mathematics for Everyone (USM) was attended by the most students (63 students from the total number 234). The comparison of the responses to the questions 9 and 10 from the post-course evaluation questionnaire realized at the beginning and at the end of evaluation period is presented in the Table 2. A statistically significant difference for the usual significance level of 0,05 was detected only for the course Local region in Teaching of Geography (MR), question 10 (see Table 2.).

Table 2. Innovated teaching - comparison

\begin{tabular}{|l|c|c|}
\hline Course & Question 9 & Question 10 \\
\hline & $p$ & $p$ \\
\hline APVM & 0,089 & 0,082 \\
\hline APVZ & 0,080 & 0,134 \\
\hline MR & $\underline{\mathbf{0 , 0 1 4}}$ & 0,069 \\
\hline USM & 0,331 & 0,298 \\
\hline USM & 0,674 & 0,227 \\
\hline USM & 0,106 & 0,941 \\
\hline RSSF & 0,527 & 0,823 \\
\hline RSCH & 0,128 & 0,155 \\
\hline SPVB & 0,327 & 0,137 \\
\hline
\end{tabular}

The Figure 3 shows the overall evaluation of the newly implemented courses based on responses to the item 10 of the post-course questionnaire. One can conclude that the implementation of the new courses is beneficial for students, because no average rating on a scale of 1-5 for any course is worse than the value of 1,8 .

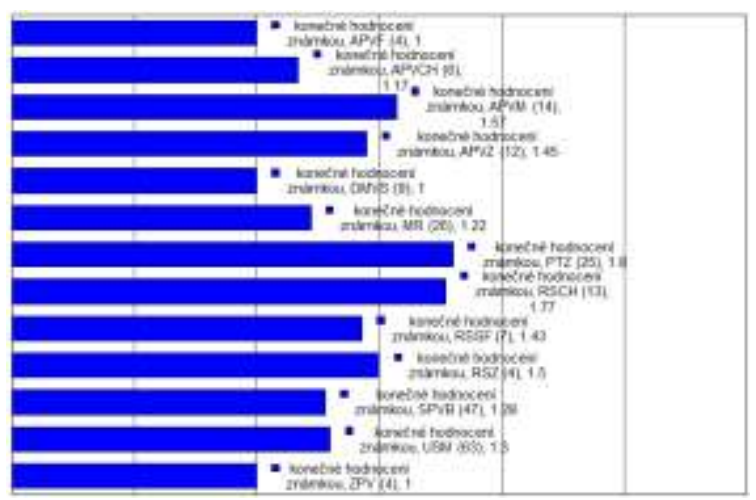

Figure 3. Overall evaluation of the courses

The comparison of responses to the items of the teacher questionnaire (Figure 1.) and student questionnaire (Figure 2.) was done within the evaluation of the teaching practice. The statistically significant difference between the teacher evaluation and the student evaluation of the teaching practice was detected for the items 1,2 and 3 in geography and for the items 1, 2, 7 and 8 in biology. The students expressions were more critical than teachers ones in all cases.

\section{Conclusions}

A general conclusion can be achieved from the evaluation: the implementation of new subjects was successful and met the expectations of the students. The new approach to the teaching practice has resulted in a stronger feedback and the subsequent creation of conditions for improvement of the practice. A scientific conference on the issue of education of science branches teachers will be organized at the end of the project. Further experience with innovated teaching and results of its evaluation should be presented. As it is usual for ESF projects, the outputs of the project should be sustainable for several years. Therefore, as well as because of the positive results of the evaluation, it is the intention of the realization team to implement new subjects as a permanent part of the study program.

\section{References}

[1] D. Bentley, D. M. Watts, Communicating in School Science: Groups, Tasks and Problem Solving, Falmer Press, London, 1992. 
[2] P. Black, D. Wiliam, “Assessment and classroom learning". Assessment in Education, 5 (1), 1998, pp. 7-74.

[3] E. G. Guba, Y. S. Lincoln, Effective evaluation, Jossey-Bass, San Francisco, 1981.

[4] V. Lamanauskas, "The Evaluation Strategies of Integrated Science Teaching and Learning". Problems of Education in the $21^{\text {st }}$ Century, 31, 2011, pp. 5-6.

[5] V. Lamanauskas, M. Vilkoniené, European Dimension in Integrated Science Education (Training Material for Students), Palacký University Press, Olomouc, 2008.

[6] M. G. Lodico, D. T. Spaulding and K. H. Voeghtle, Methods in Educational Research. Jossey-Bass A Wiley Imprint, San Francisco, 2010.

[7] J. F. Westat, The 2002 User Friendly Handbook for Project Evaluation, National Science Foundation, 2002.

\section{Acknowledgements}

This work was supported by the project CZ.1.07/2.2.00/15.0310 "Professional science teacher training for careers in a competitive environment". 